\title{
Adoption of Technology and Augmentation of Resources for Teaching-Learning in Higher Education
}

\author{
P. M. Suresh Kumar \\ Srinivas Institute of Management Studies, Pandeshwar, Mangalore - 575001, INDIA. \\ E-Mail: sureshpmsk@rediffmail.com
}

Type of the Paper: Research Paper.

Type of Review: Peer Reviewed.

Indexed in: OpenAIRE.

DOI: https://doi.org/10.5281/zenodo.800707.

Google Scholar Citation: IJMTS

\section{How to Cite this Paper:}

Suresh Kumar P. M. (2016). Adoption of Technology and Augmentation of Resources for Teaching-Learning in Higher Education. International Journal of Management, Technology, and Social Sciences (IJMTS), 1(1), 93-98.

DOI: https://doi.org/10.5281/zenodo.800707.

International Journal of Management, Technology, and Social Sciences (IJMTS)

A Refereed International Journal of Srinivas University, India.

(C) With Authors.

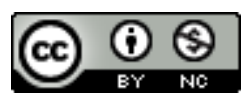

This work is licensed under a Creative Commons Attribution-Non Commercial 4.0 International License subject to proper citation to the publication source of the work.

Disclaimer: The scholarly papers as reviewed and published by the Srinivas Publications (S.P.), India are the views and opinions of their respective authors and are not the views or opinions of the SP. The SP disclaims of any harm or loss caused due to the published content to any party. 


\title{
Adoption of Technology and Augmentation of Resources for Teaching-Learning in Higher Education
}

\author{
P. M. Suresh Kumar \\ Srinivas Institute of Management Studies, Pandeshwar, Mangalore - 575001, INDIA. \\ E-Mail: sureshpmsk@rediffmail.com
}

\begin{abstract}
Learner centred education through appropriate methodologies facilitates effective learning as teaching-learning modalities of higher education are considered to be relevant to the learner group. Curriculum delivery and pedagogy should incorporate multitude of learning experiences and innovative learning methodologies through adoption of technology. Plenty of resources external to the curriculum come into use, which offer valuable learning experiences. Augmentation of resources for teaching-learning process would enhance the quality of learning. The role of the institution is to identify and provide such experiences using these resources so as to improve their learning through the alround learning opportunities available to them. Institutional strategy to nurture critical thinking, creativity and scientific temper among the students is to transform them into lifelong learners and innovators. Teaching-learning process should be mutually complementary where both the teacher and the taught gain as a result of the diversity of learning experiences. This paper discusses how technology adoption practices and augmentation of resources contribute to learning in a higher education institution.
\end{abstract}

Keywords: Technology Adoption, Augmentation of Resources, Teaching-Learning Process.

\section{INTRODUCTION :}

The primary business of educational institutions is to facilitate teaching - learning process. If this has to be effective, curriculum design, development and delivery, better and improved ways of pedagogy, competent faculty, support services and infrastructure are important [1]. The teachers should continuously innovate and adopt student centric/learner centric learning methods [2]. Although it is true that the diversity of learners in respect of their background, abilities and other personal attributes influence the pace and extent of learning, learner-centred education calls for appropriate methodologies that can be used by teachers to provide a variety of learning experiences including individual and collaborate learning [3]. Curriculum delivery and pedagogy should incorporate multitude of learning experiences based on project based learning, lab. Based learning, experiential learning, activity based learning, field based learning, technology based learning, community based learning, analytical learning, observation based learning, team based learning, social service based learning etc [4]. Adequate infrastructure facilities and resources are key for the effective and efficient conduct of the programmes. The supportive facilities on the campus contribute to the effective ambience of curriculum, extra-curriculum and administrative activities. Effective integration of technology can make learning student friendly [5]. The role of the institution is to identify and provide such experiences using these resources so as to improve their learning through the alround learning opportunities available to them [6]. A plethora of innovations and best practices evolve in course of time through such efforts to make the institution outstanding [7].

\section{TECHNOLOGY ADOPTION IN LEARNING :}

Technology has come into use in education in a big way in the recent times [8]. Higher education ought to absorb and integrate it in 
evolving teaching learning methods [9]. The following is an account of the technology adoption practices in a higher education institution.

- LCD Projectors in class : Classrooms equipped with LCD projectors. Power point presentations can make teaching more effective.

- Audio Visual Aids : Video case studies, movie clippings on management concepts, short films and advertisements could explain certain topics more effectively.

-WI-fi Campus : WI-fi enabled campus with high speed internet connectivity could help use internet facility to show real time information on industry, market and economy to the students in the class rooms.

- Computer Labs: Computer labs enables students to work on applications or internet for sourcing information.

- TV : Television installed in the college can tune channels like Business news to help the students to update themselves on current and academically relevant issues.

- Digital Library : The faculty gives assignments to students which would require to use the digital library. The digital library enables the students to get research reports, case studies and any other relevant information required to complete the given assignments.

- Public Address System : Classrooms and auditorium are equipped with the public address system. Each classroom has a hand mike, collar mike and speakers. This helps the students and faculty members in their presentations, events like subject quiz and interactions in the classroom.

- Surveillance Camera based Monitoring in the Campus : The centralized surveillance facility through fixed cameras in all classrooms give real time as well as records discipline in the class which helps monitoring for effective teaching.

- Internet Based Library Services : The faculty members can avail various internet based library services such as accessing various journals, Industry and research databases, other services from Delnet, EBSCO, etc. and internal library resource facilities which are linked to the institutional website.

- National Mission on Education through Information and Communication Technology
(NME-ICT): The faculty members can also avail information and services provided by National Mission on Education through Information and Communication Technology to prepare their study materials, lectures, and for advanced information.

- High Speed Printers \& Scanners Facility: Although sparingly in use, the high speed printers and scanners are helpful to the faculty to prepare multiple copies of case studies, business game etc.

- NPTEL Video lectures: The institute encourage watching NPTEL video lecturers of IIT professors in the area of Computer Science, Business Management and social Science by downloading such videos and issuing the CD's of such lectures in library.

- Virtual Lab : Through simulation in virtual lab, e-learning is enhanced.

- Digital Camera \& Videography Facility : Through digital videography classroom presentations are replayed to serve as feedback for improved learning.

- Open Educational Resources : Training of use of Open Courseware by MIT \& Sloan School of Business, IIM's, IIT's, IISC \& IIIT's.

- Training \& usage of Open Source Software from AICTE websites.

- Training on finding \& use of case studies from various free sources.

- Training on online Job hunting through online job service providers.

- Training on finding \& use of online text books from various websites.

- Training on finding \& use of edX consortium online courses

- Mobile Education : The institute takes the faculty to the community/ industry as a part of learning through mobile education. Some of the Faculty Development Programs are conducted outside the college to enhance the effectiveness of training.

\section{EXTERNAL RESOURCES FOR ENHANCEMENT OF LEARNING :}

Plenty of avenues are open to adopt learning [10]. It is important because such exposures are a vital source to upgrade knowledge and skills beyond the confines of curriculum [11]. Students and faculty obtain opportunities to advance level of knowledge and skills [12] through such means. 
- Seminars - Seminars, symposium and conferences conducted periodically encourage student participation. Students also participate in similar programmes by other institutions.

- Workshops - Workshops/Trainings are organized periodically.

- Guest lecturers - Experts from industry \& NGO deliver the lectures on various ongoing issues and current happenings in the corporate world/community to provide real time information and knowledge to the students.

- Blended learning - In addition to chalk and talk method of teaching, the faculty members use the IT enabled learning tools such as PPT, Video clippings, Audio system, Online sources, Simulation software, Communication lab and Decision making games and Field work conference to expose the students to combine advanced knowledge with practical learning.

- Certificate Programmes: A large number of Certificate programmes are offered to build employability skills in students and reduce the gap between curriculum and industry.

- Research Based Projects: All courses offer Research based projects for preparing dissertation through guidance and supervision.

- Practical Assignments: Assignments are required to be submitted by the students on various topics which is within the curriculum. This is taken for calculating internal assessment marks.

\section{INNOVATIONS IN TEACHING - LEARNING APPROACHES :}

Various teaching-learning methods adopted by the Institution to make learning student centric [13] are discussed below.

- Project based learning: Minor projects are undertaken by groups of students in different courses. On the completion of the projects, the team present the same and this is assessed for award of suitable marks/grades.

- Lab based learning: The Institute has computer lab with internet facility. Students gain hands on experience and obtain technology enabled real time information on subjects.

- Experiential learning: Case studies framed jointly by faculty and students recalling their experience during visits and observations help improve the understanding of the subject. This includes managerial styles, superior and subordinate relationship, interpersonal communication, problem solving etc [14]. Students offer short-term assignments in industry to gain practical experience of working in industry.

- Theater based learning: Students are required to enact / explain certain concept through theater performance like role play, drama or short play on the assigned topics.

- Simulation games: To give a real time experience of the business problems, simulation games are played in the classrooms. Students get a real feel of decision making, problem analysis and problem solving.

- Video case study: Students involve in special projects like making video case studies on specific topics.

- Activity based learning: Students involve in various activities and management games related to topics based on the subject of their study.

- Technology Based Learning : The internet, LCD, different application software etc. enable technology based learning.

- Learning from Nature \& Environment : Rural camps are conducted meant to learn from nature and environment.

- Community Based Learning : Activities conducted by students in neighbouring communities as part of village adoption provide community based learning.

- Field Work Based Learning: Field work practicum as part of the curriculum sensitize the students to social issues.

- Analytical Learning: Quantitative techniques of analysis are used in learning by students.

- Team Based Learning: The sum of individual performance is always less than team's performance. Hence in software development, team based learning is made use of.

- Observation based Learning: Demonstrations such as role play facilitates observation based learning.

- Social service Based Learning: Community interactions help, build and develop interpersonal relationship through which social service is channelized. 


\section{AUGMENTATION OF RESOURCES FOR TEACHING - LEARNING PRO CESS :}

Library is an important resource to be augmented in teaching-learning process. A variety of ways could be adopted.

- Library hour : Encouraging and enabling use of library is best possible if pre-designated library hours are introduced in every day schedule. Publications, books and other available resources could be utilized during the library hour. Various facilities available in the library databases from various websites help students get in-depth information and knowledge about subjects taught in the classroom.

- Library based projects and assignments: The faculty members help students designs projects and assignments for which the students are required to refer to the resources available in the library.

- Simulated learning through digital library: Students are exposed to the stock market operations and trading through simulated online games available with the digital library of the college.

- Library based research work: Students are exposed to various sources of online information and instructed to carry out the fundamental and technical analysis practically. The faculty members extensively use the library and the digital library for class preparation and for research purposes and collect business case studies for class room discussion.

- Library linked Information system on Website : Library provides old question papers as well as study materials of concerned subjects through institutional website. Students can access them from their home whenever required. They can also find availability of text books and project reports subject wise sitting in home.

- Collection of Educational CD's \& NPTEL Learning Resources : The library has vast collection of Soft-skill based CD's and Subject wise NPTEL video lecture CD's for student reference. Students are allowed to copy these resources in their laptop/pen drive.

- Collection of IIM Study materials: A large collection of Study materials is maintained in order to sensitize the students with resources of reputed B-Schools.

- Collection of Project Reports: The library maintains vast collection of project reports. These reports could be used by students at the time of planning and preparing their projects.

- Availability of Digitized Textbooks for Students: Rare and expensive books are available in digitized form with the library. These are available to the students for internal usage based on request.

- Book Exhibition: Library organizes book exhibitions of various publishers periodically. Students and faculty can suggest new useful books to be procured and added to the collection of books in the library from such exhibitions.

\section{CONCLUSION :}

Purpose of education is undoubtedly the overall development of students. The aim is not to create and equip workforce and produce more machines into the world of machines around us. The student is not supposed to become a workhorse. Learning is intended to inculcate scientific temper and spirit of service which would be conducive to his personal growth and transform him into economically productive, socially committed, emotionally balanced, intellectually robust and spiritually satisfied person [15]. Plenty of techniques come into use. In today's world, technology has gained entry in all fields including education. Conventional learning methods cannot deliver the intended outcome if technology takes a back seat. The need is to dovetail technology into pedagogy so that internal resources are better utilized, external resources are tapped and more innovative approaches are derived. Learner centred education through appropriate methodologies facilitates effective learning and innovative learning methodologies including adoption of technology would enhance the quality of learning.

\section{REFERENCES :}

[1] P. M. Suresh Kumar, Curriculum Enrichment for Learning Outcomes in Higher Education, International Journal of Scientific Reserarch and modern Education (IJSRME), Vol. 1, Issue II, 2016. ISSN 2455-5630. 
[2] P. M. Suresh Kuamar, Leadership Development and Quality Enhancement in Higher Education, International Journal of Advanced Trends in Engineering and Technology (IJATET), Vol. 1, Issue I, 2016. ISSN : 2456-4664.

[3] P. M. Suresh Kumar, Stakeholder Perception and Academic Improvements in Higher Education, International Journal of Advanced Trends in Engineering and Technology (IJATET), Vol. 1, Issue I, 2016. ISSN : 2456-4664.

[4] Dr. P. S. Aithal, P. M. Suresh Kumar and Deekshitha, Societal Expectation And Institutional Accountability In Higher Education, International Journal of Management, IT and Engineering (IJMIE), Volume 5, Issue 7, pp. 361-373, (July 2015), ISSN: 2249-0558, I.F. 5. 299.

[5] Dr. P. S. Aithal, P. M. Suresh Kumar and Pavithra Kumari, Methods And Approaches For Employability Skill Generation In Higher Educational Institutions, International Journal of Management, IT and Engineering (IJMIE), Volume 5, Issue 7, pp. 390-410, (July 2015), ISSN: 2249-0558, I.F. 5. 299.

[6] A. Srinivas Rao, P. M. Suresh Kumar, \& P. S. Aithal, Strategic Planning in Higher Education Institutions : A Case Study of SIMS - Vision 2025, International Journal of Educational Science and Research; Vol.5 Issue 2, April 30, 2015, pp. 29-42. ISSN 2249-6947, I. F. 3.97.

[7] P. S. Aithal, A. Srinivas Rao, \& P.M. Suresh Kumar, How Innovations and Best Practices can Transform Higher Education Institutions : A case study of SIMS, International Journal of Management (IJM), Volume 6, Issue 2, pp.83 - 98, 2015, ISSN 0976-6502, IF = 7.89 .

[8] P. S. Aithal \& P.M. Suresh Kumar, Enhancement of Graduate attributes in Higher Education Institutions through Stage Models, IMPACT: International Journal of Research in Business Management, Vol. 3, Issue 3, pp. 121 130, March 2015, ISSN 2347-4572, I.F.
1.54.

[9] P. S. Aithal, A. Srinivas Rao \& P. M. Suresh Kumar, Quality Enhancement in Higher Education Institutions : A case study of SIMS. International Journal of Multidisciplinary Research and Development, Vol. 2, Issue 5, pp. 18-31, May 2015, ISSN 2349-4182,, I.F. =3.76.

[10] Dr. P. S. Aithal and P. M. Suresh Kumar. Applying SWOC Analysis To An Institution Of Higher Education. International Journal of Management, IT and Engineering (IJMIE), Vol. 5, Issue 7, pp. 231-247, (July 2015), ISSN: 22490558, I.F. $=5.299$.

[11] P. S. Aithal \& P.M. Suresh Kumar, Student Performance and Learning Outcomes in Higher Education Institutions, International Journal of Scientific Research and Modern Education (IJSRMA). Vol.1, Issue 1, 2016. ISSN:2455-5630.

[12] P.S. Aithal \& P.M. Suresh Kumar, Catering Stduent Enrollment and Retaining Diversity in Higher Eduction Institutions, International Journal of Engineering Research and Modern Education (IJERME) Vol.1, Issue 1, 2016. ISSN:2455-4200.

[13] P.S. Aithal \& P.M. Suresh Kumar, Academic Support through Information System : Srinivas Integrated Model, International Journal of Scientific Research and Modern Education (IJSRME). Vol.1, Issue 1, 2016. ISSN:2455-5630.

[14] P.S. Aithal \& P.M. Suresh Kumar, Maintianing Teacher Quality in Higher Education Institutions, International Journal of Current Research and Modern Education (IJCRME). Vol.1, Issue 1, 2016. ISSN:2455-5428.

[15] P. S. Aithal \& P. M. Suresh Kumar, Teaching-Learning Process in Higher Education Institutions, International Journal of Multidisciplinary Research and Modern Eduction (IJMRME). Vol.2, Issue 1, 2016. ISSN:2454-6119. 